\title{
Morphological variation, species delimits, and phylogenetic relationships of four important Ipomoea species in Sri Lanka
}

\author{
P.G.R.G. Rathnayake1, R. Salih1, W.W.M.U.K. Wijesundara1, W.G.A.S. Sumanarathne' ${ }^{1}$, L. T. Ranaweera1, \\ H. S. M. Jayarathne ${ }^{1}$, C. K. Weebadde ${ }^{2}$, and S. D. S. S. Sooriyapathirana ${ }^{1,3^{*}}$
}

\begin{abstract}
${ }^{1}$ Department of Molecular Biology and Biotechnology, Faculty of Science, University of Peradeniya, Peradeniya (20400), Sri Lanka.
\end{abstract}

${ }^{2}$ Department of Plant, Soil and Microbial Sciences, College of Agriculture and Natural Resources, Michigan State University, East Lansing, MI 48824, USA.

${ }^{3}$ Postgraduate Institute of Science, University of Peradeniya, Peradeniya (20400), Sri Lanka.

\section{Correspondence:}

1,3sunethuop@gmail.com ORCID: 0000-0002-5592-1742

\begin{abstract}
Genus Ipomoea is the largest of the family Convolvulaceae. It is a highly diverse genus distributed all around the world. In Sri Lanka, 13 members have been identified in Ipomoea; however, most of them have not been morpho-genetically characterized. In the present study, we selected I. batatas, I. aquatica, I. nil, and I. pes-caprae for the assessment based on certain criteria viz., food security, leafy vegetable, emergent weed, and coastal conservation capabilities. The morphological variation, species delimits, and phylogenetic relationships among these four species were assessed. The DNA was extracted from young leaf samples using CTAB method and subjected to PCR using ITS and $r b c L$ as markers. The PCR products were subjected to sequencing. The DNA sequences were analyzed, and phylogenetic trees were generated by using PAUP to define the species delimits, identify the speciation and evolutionarily relationships in comparison to the homologous Ipomoea sequences available in GenBank. The tuber bearing ability, flower colour, and leaf shape are the key morphological descriptors that can be used to delimit the selected species. Both $r b c L$ and ITS markers could be used to identify the four species studied distinctively. However, among the two markers, ITS provides a greater variation to identify the four species and their evolutionary relationships. Thus, the present study provides a key platform with usable morphological traits and DNA barcoding markers to characterize all Ipomoea species in Sri Lanka.
\end{abstract}

Keywords: Convolvulaceae, I. aquatica, I. batatas, I. nil, I. pes-caprae 


\section{Introduction}

Ipomoea is a plant genus containing a group of warm climate trees, vines, and shrubs that are distributed mostly in the tropical and temperate zones in the world. Ipomoea is a highly diverse genus comprising of more than 500 different species. Hence, it is the largest genus in the flowering plant family Convolvulaceae, which predominantly consists of 1650 tropical species grouped into 50-60 genera (Austin and Huáman 1996). Most species in Convolvulaceae are climbing or twinning woody or herbaceous plants that frequently possess heart-shaped leaves and funnel-shaped flowers (Lobin 1986). Except for the flowers and leaves, these plants exhibit different morphological features and variations in their distribution within different environmental and geographical locations. Sri Lanka is one of the tropical countries with very high diversity, which includes 13 species of the genus Ipomoea (Table 1). Among them, four species, I. batatas, I. aquatica, I. nil, and I. pescaprae, were selected for the assessment in the present study based on food and medicinal values, weed properties and ecological and soil conservation properties respectively.
I. batatas (sweet potato) is the most abundantly found Ipomoea species in Sri Lanka. It is a herbaceous creeping plant with smooth green leaves with purple pigmentation along the veins (Wickramasinghe et al. 2009). I. batatas contains both tuberous roots and fibrous roots. The former is considered as a root vegetable, a major food source, where people consume the sweet-tasting, large, starchy tuberous roots. The tubers are rich in minerals such as sodium, potassium, calcium, and vitamin D (Izawa and Okamoto 1959). The tuber also contains $12 \%$ of the dietary fibre. The leaves of I. batatas are also consumed occasionally. The leaves contain appreciable levels of important nutrients such as manganese, potassium, zinc, sodium, magnesium, calcium, iron, and vitamin C (Antial et al. 2006). In addition to serving as an indispensable constituent of the human diet, I. batatas is used to treat cancer, diarrhea, nausea, and asthma in Ayurvedic medicine utilizing its antimicrobial, antioxidant, demulcent, and astringent properties (AMPSL 2020).

I. aquatica (water spinach) is a semiaquatic leafy vegetable grown as a green vegetable in Sri Lanka. The shoot-tops (i.e. leaves and young,

Table 1: Ipomoea spp. found in Sri Lanka

\begin{tabular}{lll}
\hline Scientific name & English name & Local Name \\
\hline I. alba & Moon vine & Alanga / Kalu alanga \\
I. aquatica & Water morning glory & Kankun \\
I. asarifolia & - & Ela binthamuru \\
I. batatas & Sweet potato & Batala \\
I. littoralis & - & Thel kola \\
I. mauritiana & Giant potato & Kiri badu \\
I. nil & Blue morning glory & Kaladana / Kalamaruva \\
I. obscura & Obscure morning glory & Maha madhu /Tel kola \\
I. pes-caprae & Goat foot vine, Bayhops & Muhudu binthamburu \\
I. pes-tigridis & Tiger foot morning glory & Divipahuru \\
I. quamoclit & Cypress vine & Rata pamba / Rathingna mal \\
I. sepiaria & Purple heart glory & Rasa thel kola \\
I. triloba & Little bell & Wasa thella \\
\hline
\end{tabular}

(Ayurveda Medical Plants of Sri Lanka 2020) 
floating stems) are harvested to make delicious dishes for consumption (Kailasapathy and Koneshan 1986). Water spinach is also rich in minerals such as vitamin $\mathrm{C}$, vitamin $\mathrm{A}$, iron, potassium, and manganese. This crop can be easily grown and harvested at irregular intervals. The water spinach cultivation requires low labor and is immune to various natural pressures (Edie and Ho, 1969; Umar et al. 2007). It is also known to control the water quality due to its ability to accumulate heavy metals (Gothberg et al. 2002). The bioaccumulation of heavy metal ions greatly hinders the food value of water spinach (Ranathunga et al. 2019).

I. nil (Japanese morning glory) is an annual climbing herb, which is capable of producing self-pollinating, ephemeral blue flowers. This is largely cultivated as an ornamental plant in many parts of the world, and there are many named varieties (Huxley 1992). Currently, in Sri Lanka, a large number has been spread in the up-country regions, which includes many tea estates and abundant lands. Due to the recent ban on using glyphosate, $I$. nil is prominently emerging as a weed causing problems such as blocking sunlight, interrupting plucking and other operations, and harboring pests and diseases in tea lands. The seeds of this plant have some rare medicinal value. I. nil is used to treat conditions like constipation, ascariasis, oliguria, and edema.

I. pes-caprae (beach morning glory) is a creeping vine that is restricted and abundantly distributed in the sandy shores of Sri Lankan oceans and throughout the tropical coastal areas. It is salt tolerant, and the seeds of this plant disperse through oceans by floating in the seawater. I. pes-caprae is also a known primary sand stabilizer and successfully grows in sandbanks. The extensive runners of this kind appear from large, thick, and woody rootstock, and the stems could extend up to $30 \mathrm{~cm}$ along with root at the nodes. This spreading pattern often results in a dense net of low growth vines covering the whole coastal line (Das and Mukherjee 1997). These mesh-like covering could protect the soil from erosion. This plant also has various uses in medicine as well as in agroforestry. The boiled roots are used to treat bladder related diseases. The leaves are used to provide relief during chickenpox conditions, dropsy, and urethral discharges; also, the stems are known to have anti-tumor properties as well (Bragadeeswaran et al. 2010).

The members of the genus Ipomoea of the family Convolvulaceae must be morphogenetically characterized to harness the food, agricultural, and ecological values. To our knowledge, no studies have been conducted to characterize and identify species delimits of Ipomoea spp. in Sri Lanka. Therefore, the present study was undertaken to assess I. batatas, I. aquatica, I. nil, and I. pes-caprae, in Sri Lanka, using morphological and phylogenetic approaches.

\section{Materials and Methods}

\section{Plant material}

Initially, the distribution of the members of the Ipomoea genus and their diversity were recorded throughout the country. Then the variation of their morphological features based 
on the islandwide distribution and diversity was assessed and four important species were chosen. Based on these observations, a total of 10 representative samples referring to four selected Ipomoea species, including I. batatas, I. aquatica, I. nil, and I. pes-caprae were collected in the natural range of Sri Lanka (Table 2). Then the voucher specimens used in this study were preserved, and their morphological features were studied.

Table 2: Locations of the collected plant materials

\begin{tabular}{lccc}
\hline Species & $\begin{array}{c}\text { Voucher } \\
\text { Number }\end{array}$ & Location & $\begin{array}{c}\text { GPS } \\
\text { Coordinates }\end{array}$ \\
\hline I. batatas & DMB09 & Peradeniya & 7.271748 \\
& & & 80.598761 \\
& DMB10 & Galle & 6.053842 \\
& & & 80.225386 \\
\hline I. aquatica & DMB06 & Peradeniya & 7.271748 \\
& & & 80.598761 \\
& DMB07 & Dambulla & 7.884588 \\
& & & 80.667958 \\
& DMB08 & Digana & 7.298066 \\
& & & 80.737409 \\
\hline I. nil & DMB192 & Nuwara-Eliya & 7.035686 \\
& & & 80.517982 \\
& DMB193 & Pussellawa & 7.109321 \\
& & & 80.639426 \\
\hline I. pes- & DMB500 & Pasikuda & 7.929618 \\
caprae & & & 81.560875 \\
& DMB501 & Moratuwa & 6.753961 \\
& & & 79.888277 \\
& DMB502 & Negombo & 7.231338 \\
& & & 79.842457 \\
& & &
\end{tabular}

\section{DNA extraction, PCR and sequencing}

Fresh leaf samples from each selected species were collected to extract DNA using the cetyltrimethylammonium bromide (CTAB) method (Doyle and Doyle 1990), and the extracted DNA samples were stored at $-20{ }^{\circ} \mathrm{C}$.
The extracted genomic DNA samples were PCR amplified using two standard plant DNA barcoding markers; rbcL and ITS (Table 3). The PCR mixture was prepared of $15 \mu \mathrm{l}$ volume, consisting of 2× GoTaq® Green Master Mix, 0.3 pmol of forward and reverse primers, and $50 \mathrm{ng}$ of template DNA. The PCR program consisted of an initial denaturation at $95{ }^{\circ} \mathrm{C}$ for $5 \mathrm{~min}, 35$ cycles with denaturation at $95{ }^{\circ} \mathrm{C}$ for $30 \mathrm{~s}$, primer annealing at $55{ }^{\circ} \mathrm{C}$ for $1 \mathrm{~min}$ and synthesis at $72{ }^{\circ} \mathrm{C}$ for $90 \mathrm{~s}$, final extension at $72{ }^{\circ} \mathrm{C}$ for $4 \mathrm{~min}$. The PCR products were purified using the QIAquick® ${ }^{\circledR}$ PCR Purification Kit (Catalog No: 28104, Qiagen, Hilden, Germany). The purified PCR products were cycle sequenced using the Genetic Analyzer 3500 (Catalog number: 622-0010, Applied Bio System).

Table 3: The primer details for the DNA barcoding

\begin{tabular}{ll}
\hline DNA marker & Sequence (5'-3') \\
\hline \multirow{2}{*}{$r b c L^{*}$} & F: ATGTCACCACAAACAGAGACTAAAGC \\
& R: GTAAAATCAAGTCCACCRCG \\
\hline \multirow{2}{*}{$I T S 1-4^{* *}$} & F: TCCGTAGGTGAACCTTGCGG \\
& R: TCCTCCGCTTATTGATATGC
\end{tabular}

*Wang et al. (2001); gene for the large subunit of the ribulose-bisphosphate carboxylase in chloroplast genome

${ }^{* *}$ White et al. (1990); internal transcribed spacer of $r R N A$ genes in nuclear genome

\section{Phylogenetic analysis}

The raw sequences resulted from automated sequencing were checked for the quality and accuracy by reading the electropherogram. The $3 \times$ sequence reads were then aligned, trimmed, and concatenated to a consensus sequence using the software MEGA 7 (Kumar et al. 2016). The datasets of Ranathunga et al. (2019) and $\mathrm{Xu}$ et al. (2018) were used with the sequences 
Table 4: The $r b c L$ and ITS sequences assessed

\begin{tabular}{|c|c|c|c|c|c|}
\hline \multirow{2}{*}{ Species } & \multirow{2}{*}{ Voucher No. } & \multirow{2}{*}{ Country } & \multicolumn{2}{|c|}{ GenBank Ac. No. } & \multirow{2}{*}{ Reference } \\
\hline & & & rbcL & ITS & \\
\hline \multirow[t]{3}{*}{ Ipomoea pes-caprae } & DMB500 & Sri Lanka & MN563135 & MN559534 & This study \\
\hline & DMB501 & & MN563136 & MN559535 & \\
\hline & DMB502 & & MN563137 & MN559536 & \\
\hline \multirow[t]{2}{*}{ I. batatas } & DMB09 & & MH796547 & MH792117 & Ranathunga et al. (2019) \\
\hline & DMB10 & & MH796548 & MH792118 & \\
\hline \multirow[t]{3}{*}{ I. aquatica } & DMB06 & & MH796544 & MH792114 & \\
\hline & DMB07 & & MH796545 & MH792115 & \\
\hline & DMB08 & & MH796546 & MH792116 & \\
\hline \multirow[t]{6}{*}{ I. triloba } & 201509146 & China & MF135366 & KY968868 & Xu et al. (2018) \\
\hline & 13365 & & MF135405 & KY968904 & \\
\hline & 201509156 & & MF135374 & KY968875 & \\
\hline & 201509190 & & MF135384 & - & \\
\hline & 201509143 & & MF135365 & KY968867 & \\
\hline & 201509172 & & MF135377 & KY968878 & \\
\hline \multirow[t]{2}{*}{ I. lacunose } & 201509150 & & MF135368 & KY968870 & \\
\hline & 201509210 & & MF135389 & KY968889 & \\
\hline \multirow[t]{2}{*}{ I. nil } & 201509152 & & MF135370 & KY968871 & \\
\hline & 201509208 & & MF135388 & KY968888 & \\
\hline I. purpurea & 201507092 & & MF135354 & KY968856 & \\
\hline I. hederfolia & 13516 & & - & KY968940 & \\
\hline Solanum pseudocapsicum & 201509147 & & MF135367 & KY968869 & \\
\hline (outgroup) & 201507061 & & MF135342 & KY968847 & \\
\hline
\end{tabular}

generated in the present study (deposited in GenBank) to create a multiple sequence alignment to assess the species delimits and phylogenetic relationships of Ipomoea spp. which got sequences in GenBank (Table 4). Solanum pseudocapsicum was used as the outgroup in the phylogenetic analysis. The ITS and $r b c L$ sequence datasets were analyzed separately. A model test was performed to assess the evolutionary process of the nucleotide substitutions. Thus, the model fitting for the datasets can be conducted in the phylogenetic analysis. The model test was performed using Akaike Information Criteria (AIC) (Akaike 1974), Modified Akaike
Information Criteria (AICc) (Cavanaugh 1997), and Bayesian Information Criteria (BIC). A total of seven substitution schemes were considered alongside with the proportion of invariants and gamma shape parameters. The complete analysis was carried out using the software, Jmodel test (Posada 2008), in CIPRES science gateway (Miller et al. 2010). The phylogenetic trees were constructed in PAUP 4.0a (Swofford 2002). The Neighbour Joining trees were drawn considering an uncorrected pairwise genetic distance matrix, and the best tree was constructed in a heuristic search implementing the tree bisection and reconstruction method. A parsimonious bootstrap analysis was 
performed for 1000 iterations to validate the tree topologies. The final 50\% consensus tree was constructed using the total trees created. The resulting trees were further modified and visualized in Figs. 1.4.3 (Rambaut 2014).

\section{Results}

\section{Morphological features of the selected Ipomoea spp.}

Vernacular name: sweet potato

Botanical name: I. batatas

Stems: greenish or red-purplish, thin stems with or without hair and contain latex, prostate, and slender. Lateral stem branches arise from the short stem and usually unbranched, height can vary from $1 \mathrm{~m}-5 \mathrm{~m}$. Leaves: light green to deep purple, simple, spirally arranged, the shape can be rounded, retiform, triangular, lobbed and almost divided, margins are entire, toothed or lobed, length varies from $5 \mathrm{~cm}-15$ $\mathrm{cm}$, width varies from $5 \mathrm{~cm}-15 \mathrm{~cm}$. Inflorescence: solitary flowers or in fewflowered cymes, glabrous. (Fig. 1a). Flowers: lavender, pale purple or white, darker in colour inside the tube, trumpet shape, up to $4 \mathrm{~cm}-7$ cm long. Fruits: dry dehiscent fruit capsule and ovoid, each capsule consists of one to four seeds, glabrous. Seeds: brown to black, irregular, slightly angular to a rounded shape. Root: fibrous roots, pentarch or hexarch. Tuberroot: skin color varies from purple, cream to brown, round or longish shape, pulp varies from white to yellow, placed closely or far from the main root. Seedlings: deeply bi-lobed cotyledons, subacute or obtuse lobes, prominent rounded auricles (Figs. 2a, 3a, and 4a) (Purseglove 1974; Lebot 2009; Hue et al. 2010).

Vernacular names: water ipomoea, storage cabbage, water spinach

Botanical name: I. aquatica

Stems: round, hollow or spongy in shape, free branching, long trailing, herbaceous, have a milky sap, length varies from $2 \mathrm{~m}-3 \mathrm{~m}$. Leaves: greenish, simple, alternatively arranged, arrowhead, or lanceolate in shape, margins are entire or with few irregular serrations or small lobes near the base, length varies from $5 \mathrm{~cm}$ $15 \mathrm{~cm}$, width varies from $2 \mathrm{~cm}-8 \mathrm{~cm}$. Inflorescence: contain solitary flowers in leaf axis, thin corolla with a broadly funnelform, free, sub-equal, five stamens, two locular and elliptic anthers, and two globose shaped stigma (Fig. 1b). Flowers: white to pale pink or lilac in colour with a mauve centre, trumpet-shaped, diameter varies from $3 \mathrm{~cm}-5 \mathrm{~cm}$, the length is about $5 \mathrm{~cm}$. Fruits: ovoid to globose shaped capsules, 4 seeded, $1 \mathrm{~cm}$ long, 0.5 inches wide. Seeds: brown, densely pilose, $7 \mathrm{~mm}$ in length, $4 \mathrm{~mm}$ wide. Root: adventitious roots, formed at nodes. Seedlings: cotyledons are petiolated, bi-lobed with V-shape (Figs. 2b, 3b, and 4b) (Jayeola and Oladunjoye 2012; Madhvi et al. 2014).

Vernacular names: beach morning glory, goats foot

Botanical name: I. pes-caprae

Stems: greenish or red-purplish, succulent with a milky latex, glabrous, occasionally twinning, angular or flattened branches, hairless or with hair, length varies from $1 \mathrm{~m}-3 \mathrm{~m}$. Leaves: simple, thick and robust, alternate leaf 
arrangement, variable in shape, lobed margin, 3 $\mathrm{cm}-14 \mathrm{~cm}$ in length, $2.5 \mathrm{~cm}-12 \mathrm{~cm}$ wide. Inflorescence: axillary, ovate or elliptic outer sepals and broader outer sepals, glabrous ovary, stamens and styles are surrounded by petals (Fig. 1c). Flowers: pink, reddish, purple or violet, large, trumpet-shaped, $3 \mathrm{~cm}-5 \mathrm{~cm}$ in length. Fruits: spherical shape, 4-locular capsule, $12 \mathrm{~mm}-17 \mathrm{~mm}$ in diameter. Seeds: brownish, four suborbicular seeds, densely hairy, $7 \mathrm{~mm}-12 \mathrm{~mm}$ in length, $6 \mathrm{~mm}-8 \mathrm{~mm}$ in diameter. Root: long, deep taproot, and small adventitious roots, 20 feet in depth. Seedlings: Each pair of cotyledons is deeply lobed and folded (Figs. 2c, 3c, and 4c) (Devall 1992; Bach 1998).

Vernacular names: Japanese morning glory, ivy morning glory

Botanical name: I. nil
Stems: slender wine, cylindrical or angular shaped, covered with hairs, $2 \mathrm{~m}-5 \mathrm{~m}$ in length. Leaves: simple, alternately arranged, 3-lobed, ovate to sub-orbicular shaped, entire margin, 4 $\mathrm{cm}-15 \mathrm{~cm}$ in length, $4.5 \mathrm{~cm}-14 \mathrm{~cm}$ in width. Inflorescence: solitary or cymes, sub-equal sepals, funnel-shaped, glabrous corolla, globular stigma, slender style and a superior ovary with 2 - 5 cells (Fig. 1d). Flowers: blue or pink with whitish tubes, funnel-form, $5 \mathrm{~cm}-6$ $\mathrm{cm}$ in length. Fruits: ovoid to a globose shaped, glabrous capsule. Seeds: black or brown, puberulous, ovoid-trigonous shaped, $5 \mathrm{~mm}-6$ $\mathrm{mm}$ in length. Root: taproot system. Seedlings: bi-lobed cotyledons, and cordate base (Figs. 2d, 3d, and 4d) (Der Marderosian et al. 1964; Kajita and Nishino 2009).

\section{Morphological key for selected Ipomoea species}

A key to identify the most abundant species within the genus Ipomoea in Sri Lanka is given below.

1 Tuberous root system; tuberous roots-purple to brown skin color, round or longish shape, placed closer to main root, pulp cream to white. I. batatas

1 Roots tap root system; I. aquatica, I. nil and I. pes-caprae

2 Flowers blue; pink with whitish tubes, funnel-form, $5 \mathrm{~cm}-6 \mathrm{~cm}$ in length. I. nil 2 Flowers pink; reddish; purple or violet, large, trumpet shaped, $3 \mathrm{~cm}-5 \mathrm{~cm}$ in length.

\section{I. aquatica, I. pes-caprae}

3 Leaves simple; thick and robust, alternate leaf arrangement, variable in shape, lobed margin, $3 \mathrm{~cm}-14 \mathrm{~cm}$ in length, $2.5 \mathrm{~cm}-12 \mathrm{~cm}$ wide. I. pes-caprae

3 Leaves simple; spirally arranged, sagittate to lanceolate, margins are entire, toothed or lobed, length vary from $5 \mathrm{~cm}-15 \mathrm{~cm}$, width varies from $5 \mathrm{~cm}-15 \mathrm{~cm}$.

\section{I. aquatica}




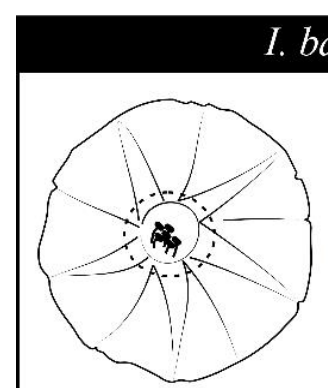

A1

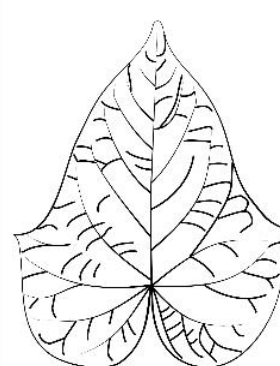

$\mathrm{A} 3$

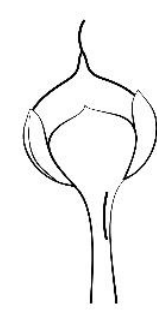

A5

I. batatas

I. aquatica

I. pes-caprae

I. nil

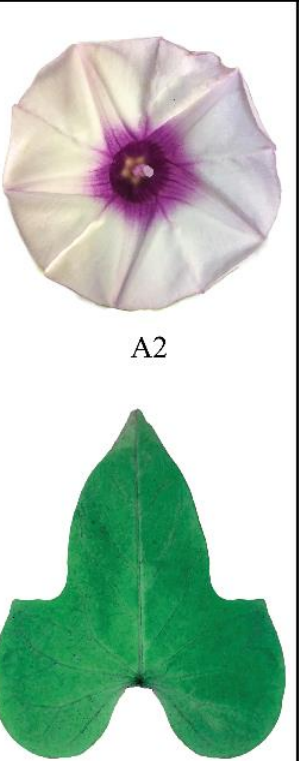

A4

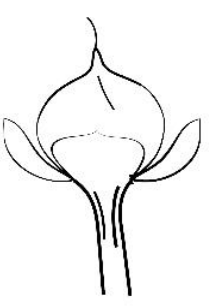

A6

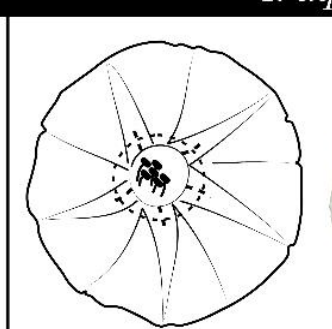

B1

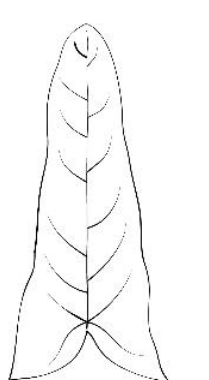

B3

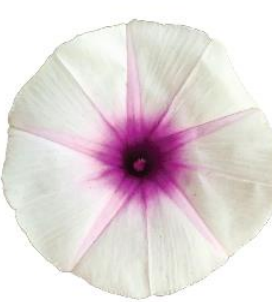

B2

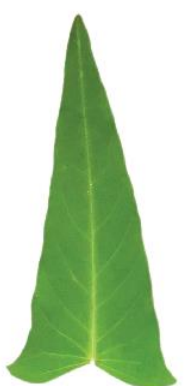

B4

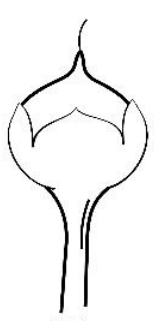

B5
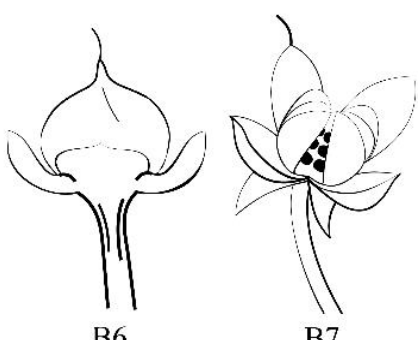

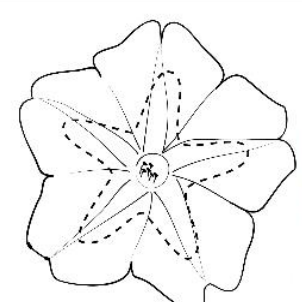

C1

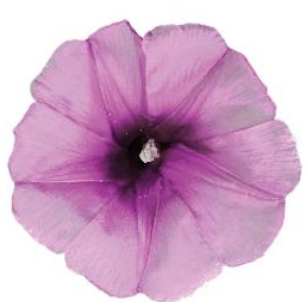

C2

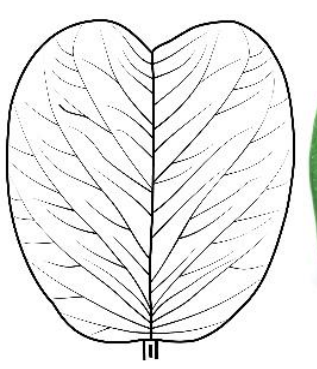

C3

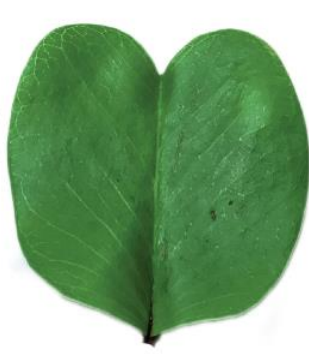

C4

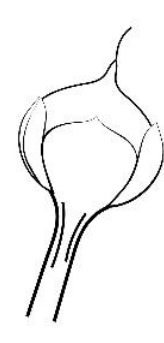

C5

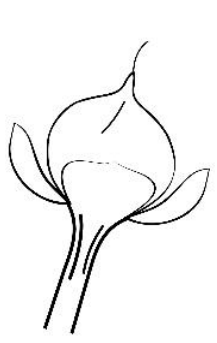

C6

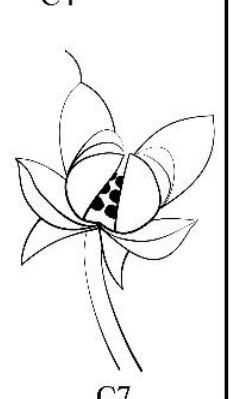

C7

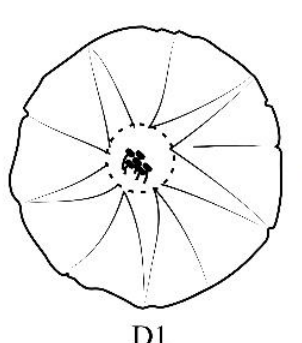

D1
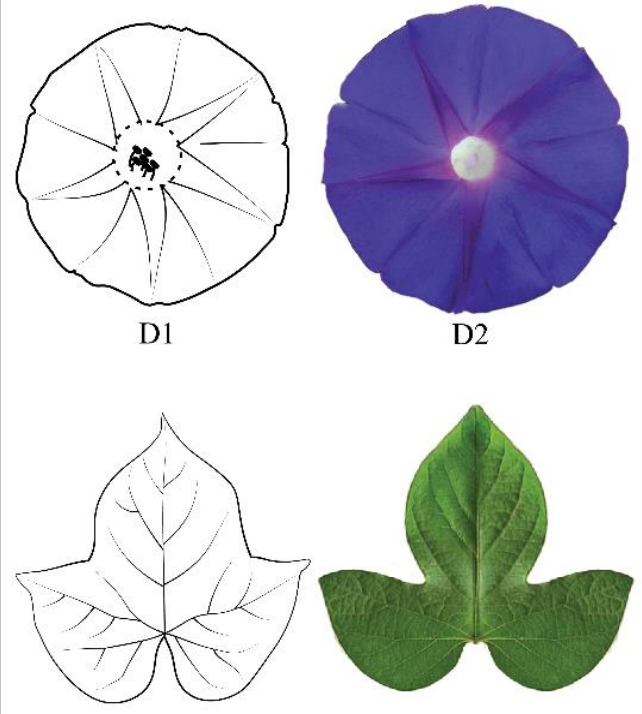

D3

D4

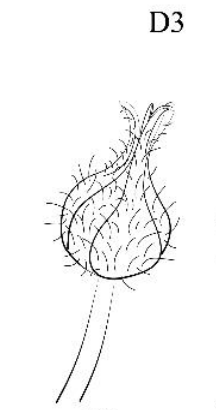

D5 view of flower, 3: Line diagram of the mature leaf, 4: Mature leaf, 5,6,7: The line diagrams of the stages of fruit development. Scale bar represents $1 \mathrm{~cm}$. 
A
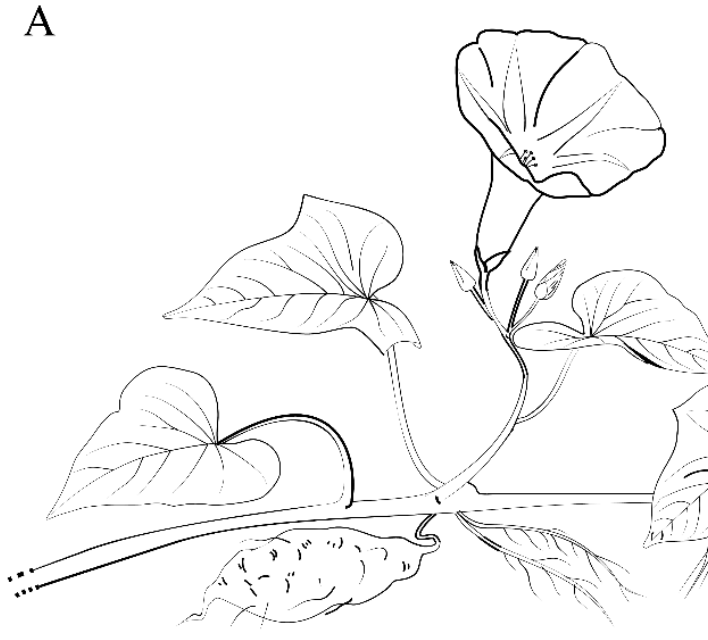

C

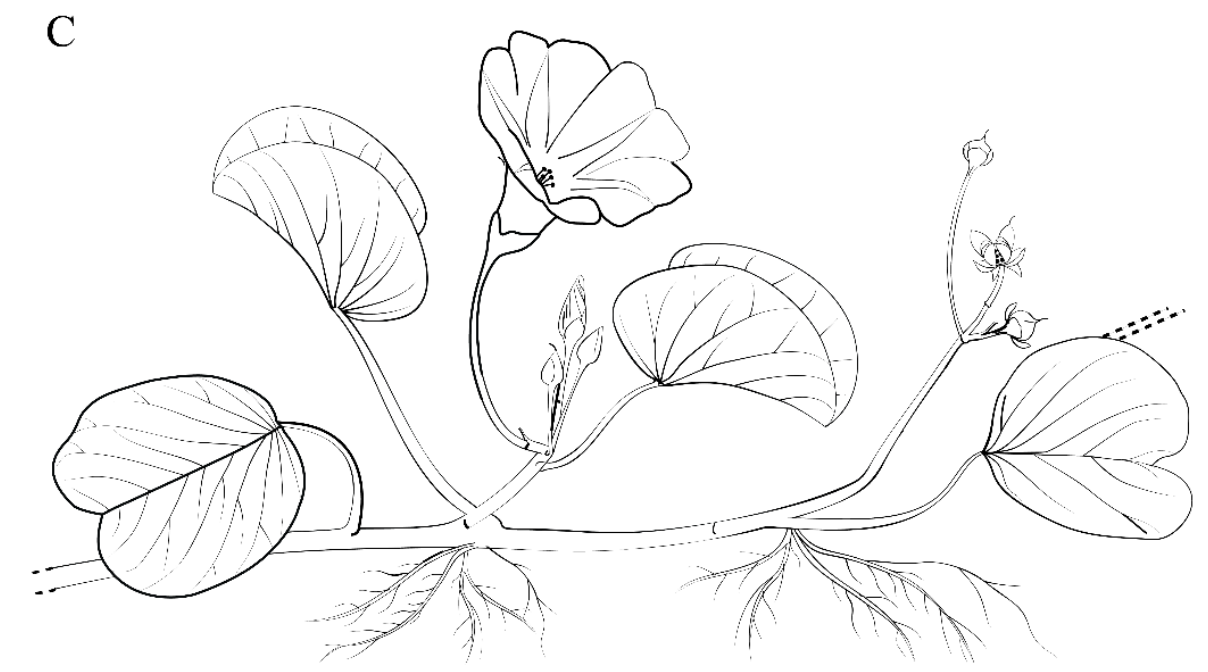

B
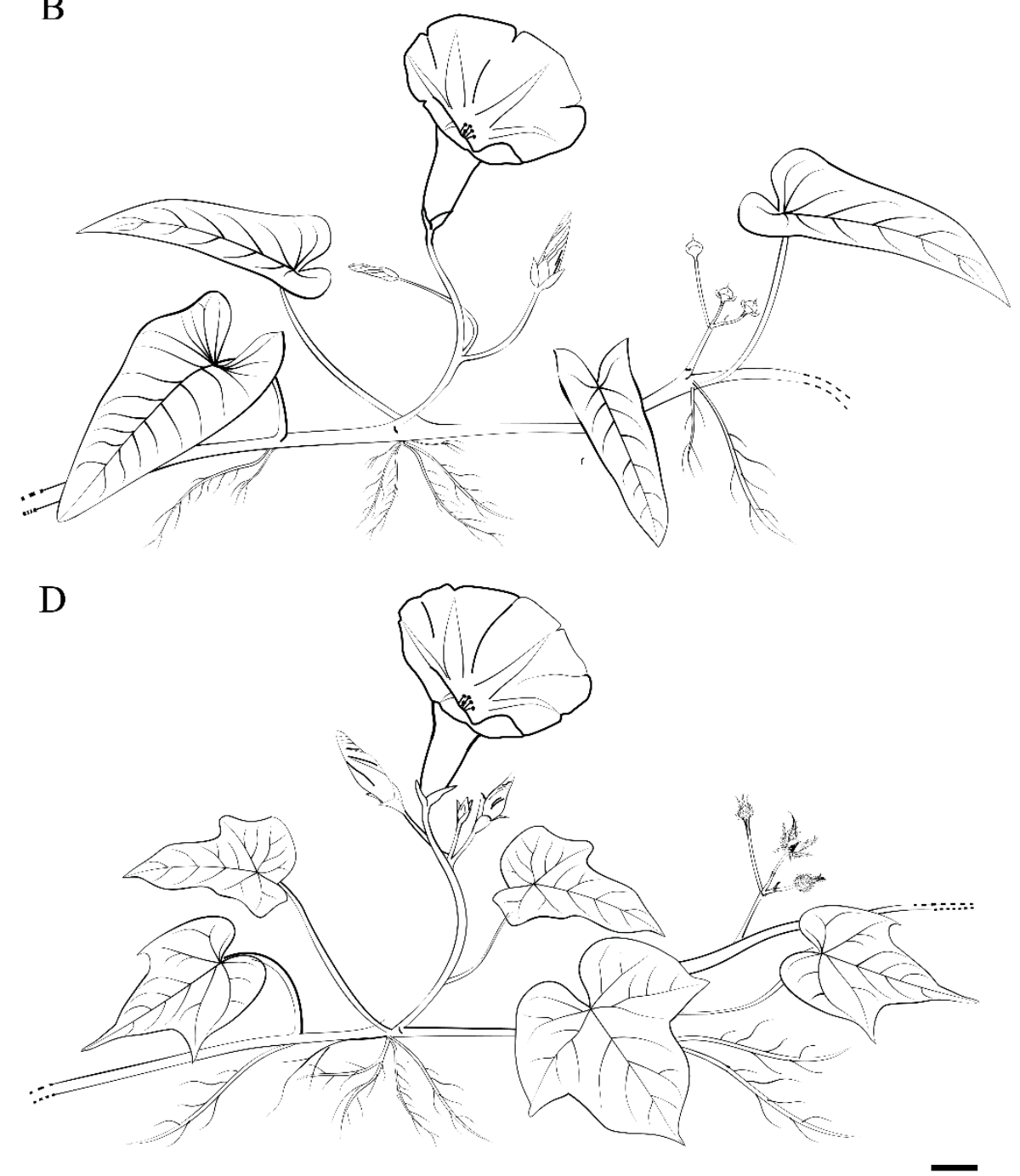

Figure 2: Line diagrams of the Ipomoea species in their natural habitats. A: I. batatas, B: I. aquatica, C: I. pes-caprae, D: I. nil. Scale bar represents $1 \mathrm{~cm}$. 
A

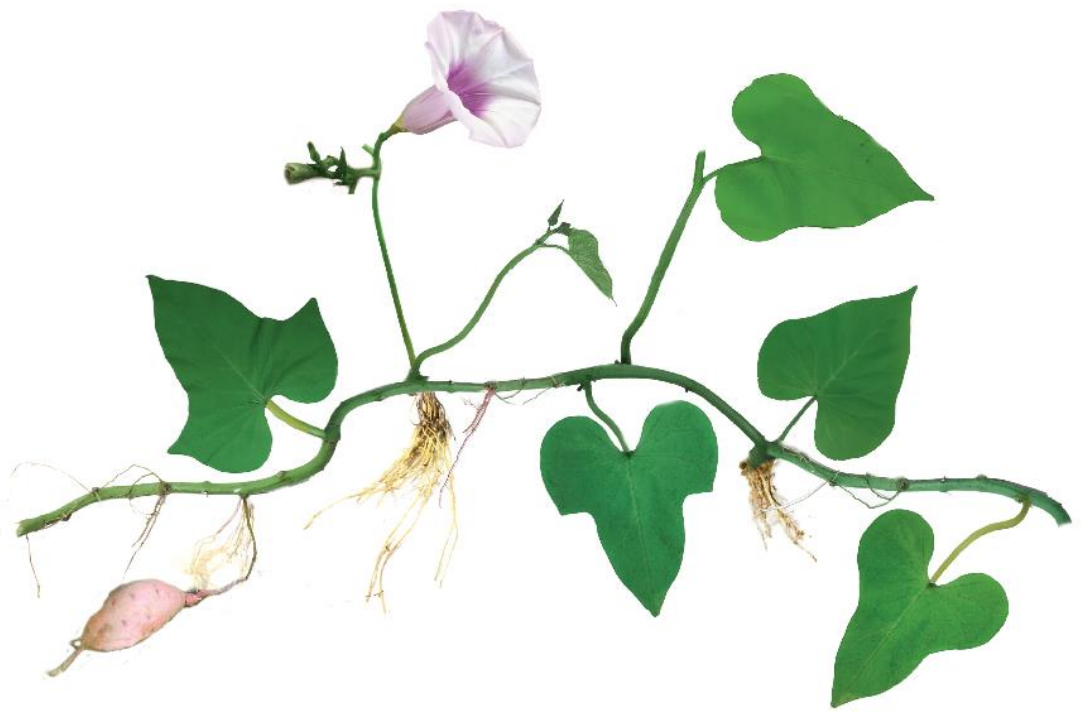

C

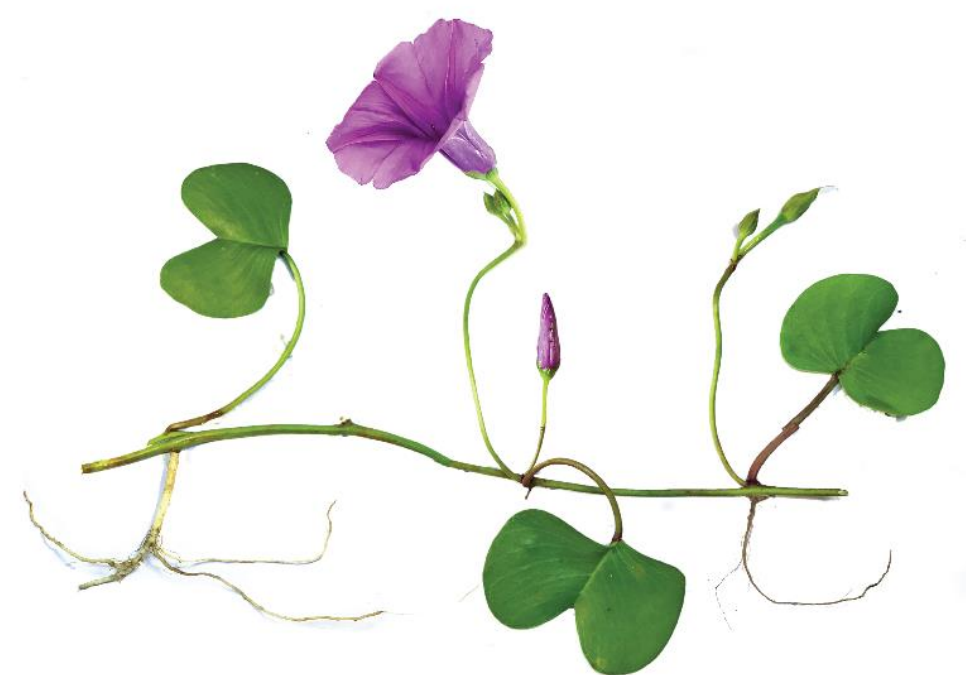

B

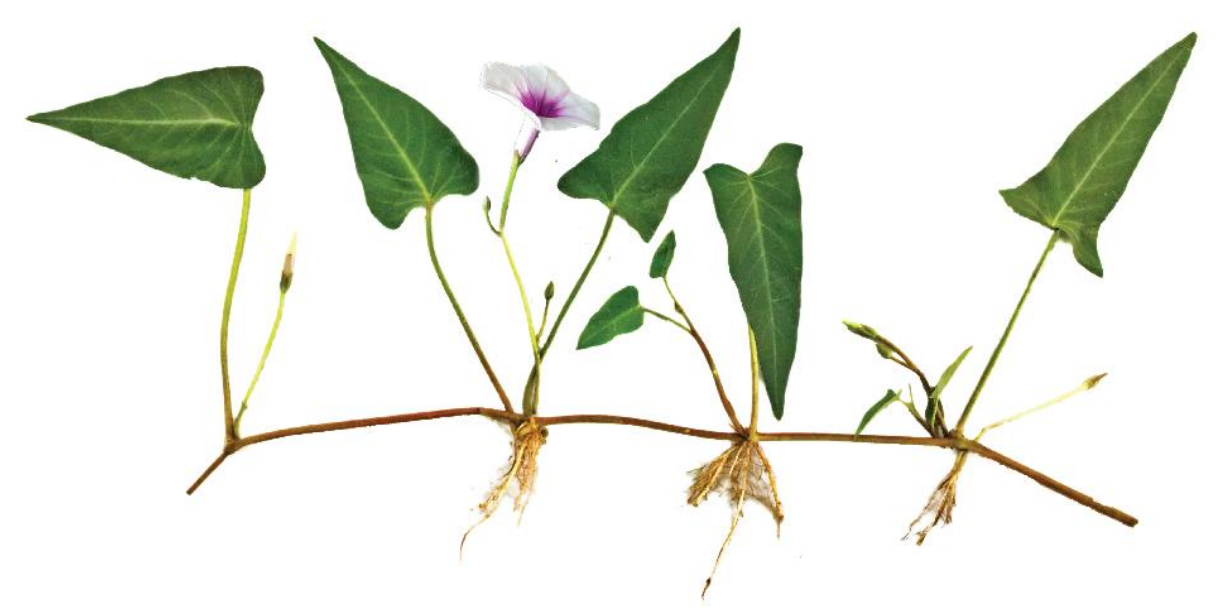

$\mathrm{D}$

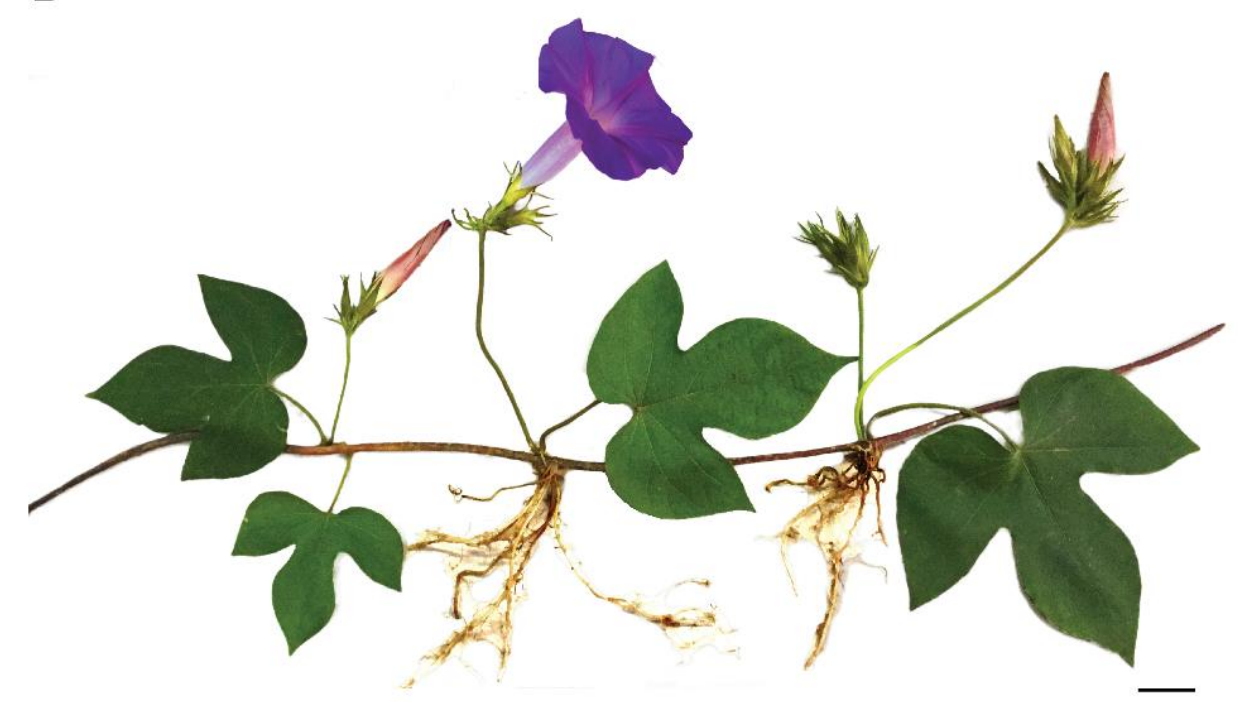

Figure 3: The morphology of the Ipomoea species in their natural habitats. A: I. batatas, B: I. aquatica, C: I. pes-caprae, D: I. nil. Scale bar represents $1 \mathrm{~cm}$. 


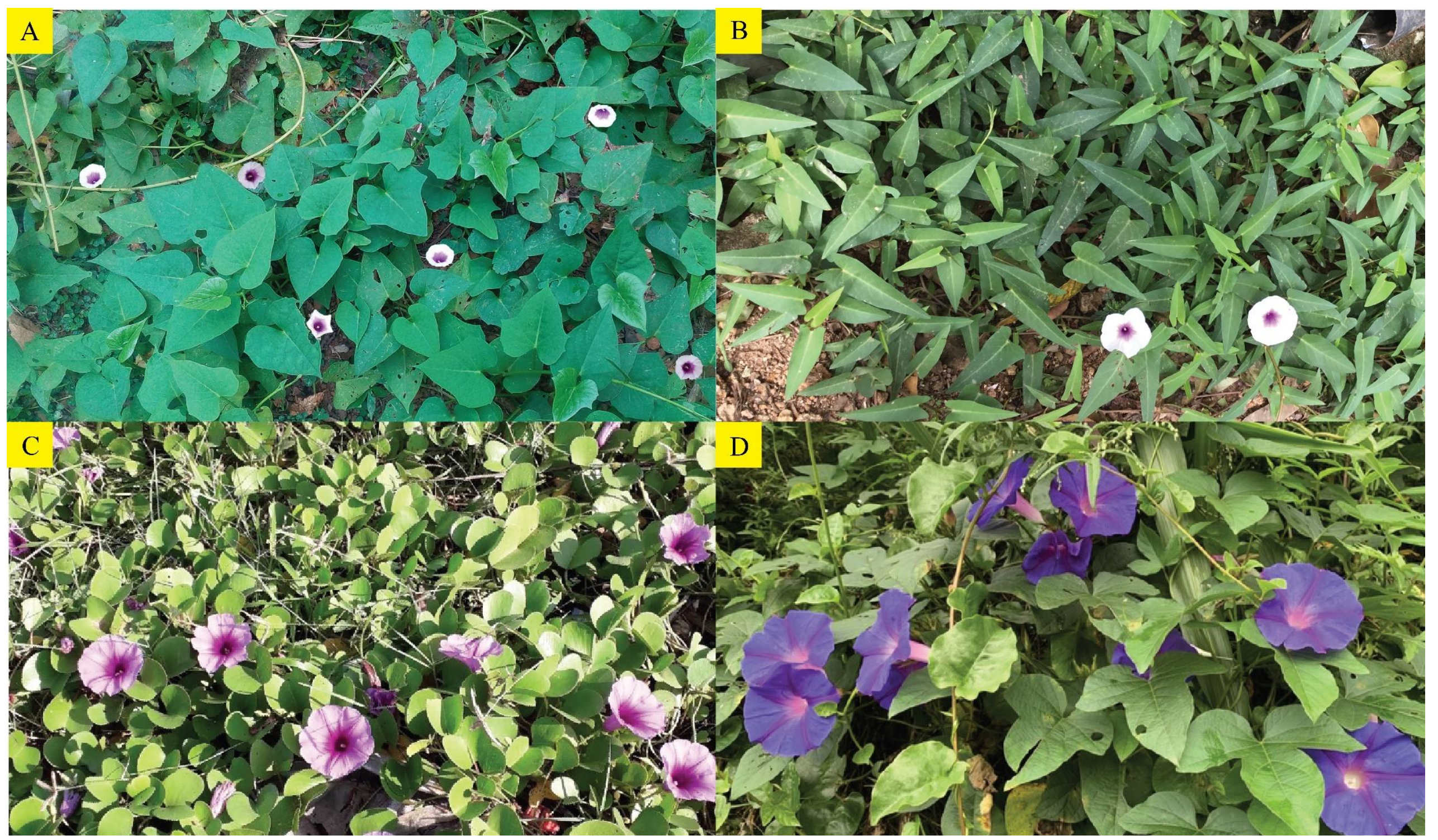

Figure 4: The selected Ipomoea species in their natural habitats. A: I. batatas, B: I. aquatica, C: I. pes-caprae, D: I. nil. Scale bar represents $1 \mathrm{~cm}$. 


\section{Species delimits and phylogenetic}

relationships: The GTR $+\mathrm{I}+\mathrm{G}$ model resulted in the best representation of the substitution schemes in both datasets for all three model evaluation criteria. Both NJ trees constructed for $r b c L$ and ITS datasets had almost similar topologies. Particularly, both trees retained the main phylogenetic relationships between each Ipomoea spp. However, the tree constructed for the $r b c L$ dataset had a low resolution at the nodes near the operational taxonomic units (Fig. 5). Especially the clade containing I. batatas, I. triloba and I. lacunose was not separated in $r b c L$ phylogeny. Moreover, the $r b c L$ phylogeny had low node support at many branches showing the low resolvability of the $r b c L$ marker. Contrastingly the ITS phylogeny was well separated with higher node support, validating the phylogenetic relationships (Fig. 6). I. pes-caprae was clade sister to I. aquatica in both phylogenies. This clade was well supported in $r b c L(b s=76)$ and ITS (bs = 100). I. pes-caprae and I. aquatica had 1\% and 5\% mean uncorrected pairwise genetic distance for $r b c L$ and ITS markers separately.

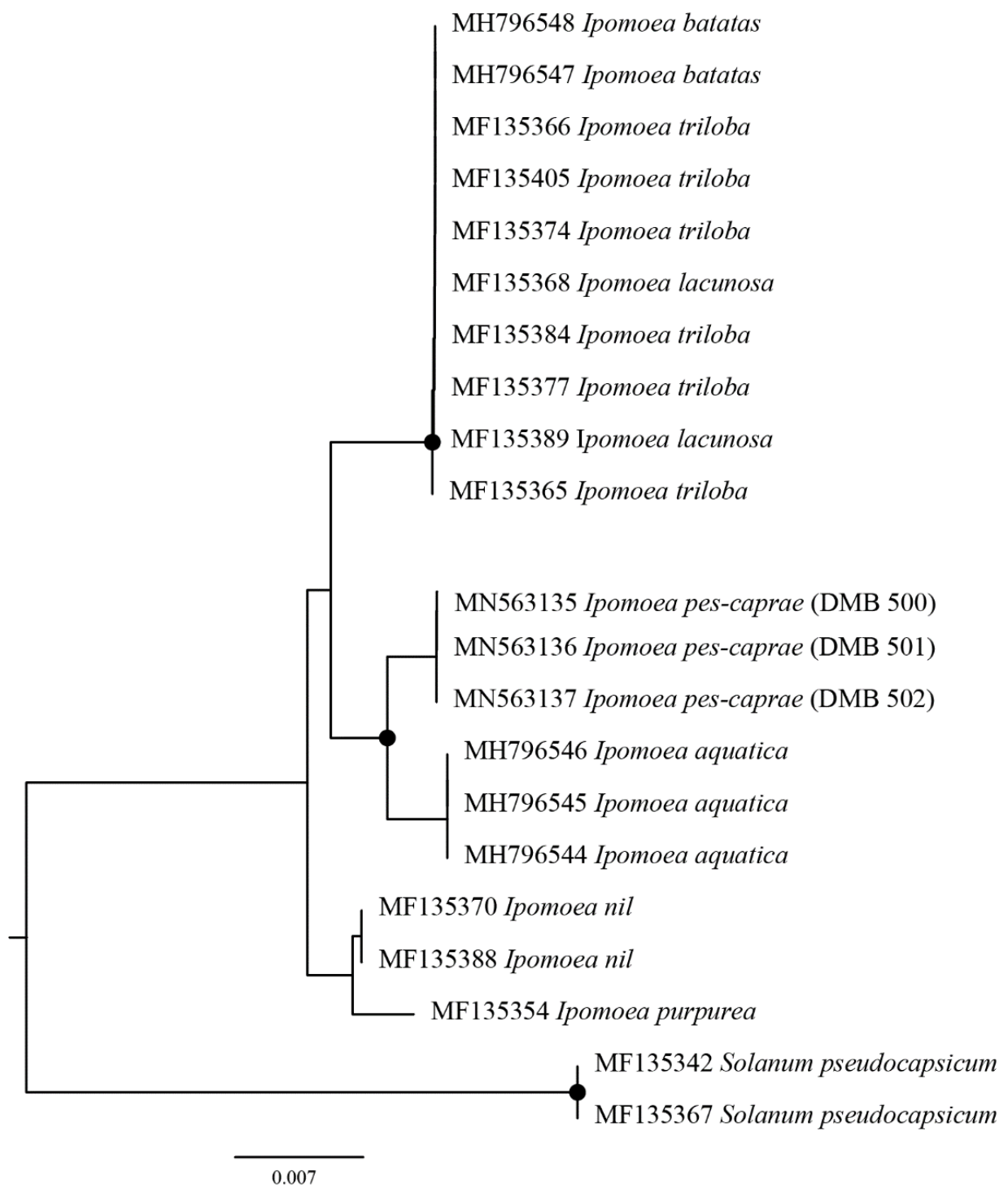

Figure 5: The NJ tree constructed for the marker $r b c L$ showing the phylogenetic relationships between Ipomoea spp. The black dots indicate the nodes that have bootstrap values over 70 . The scale bar represents the uncorrected pairwise genetic distance. 


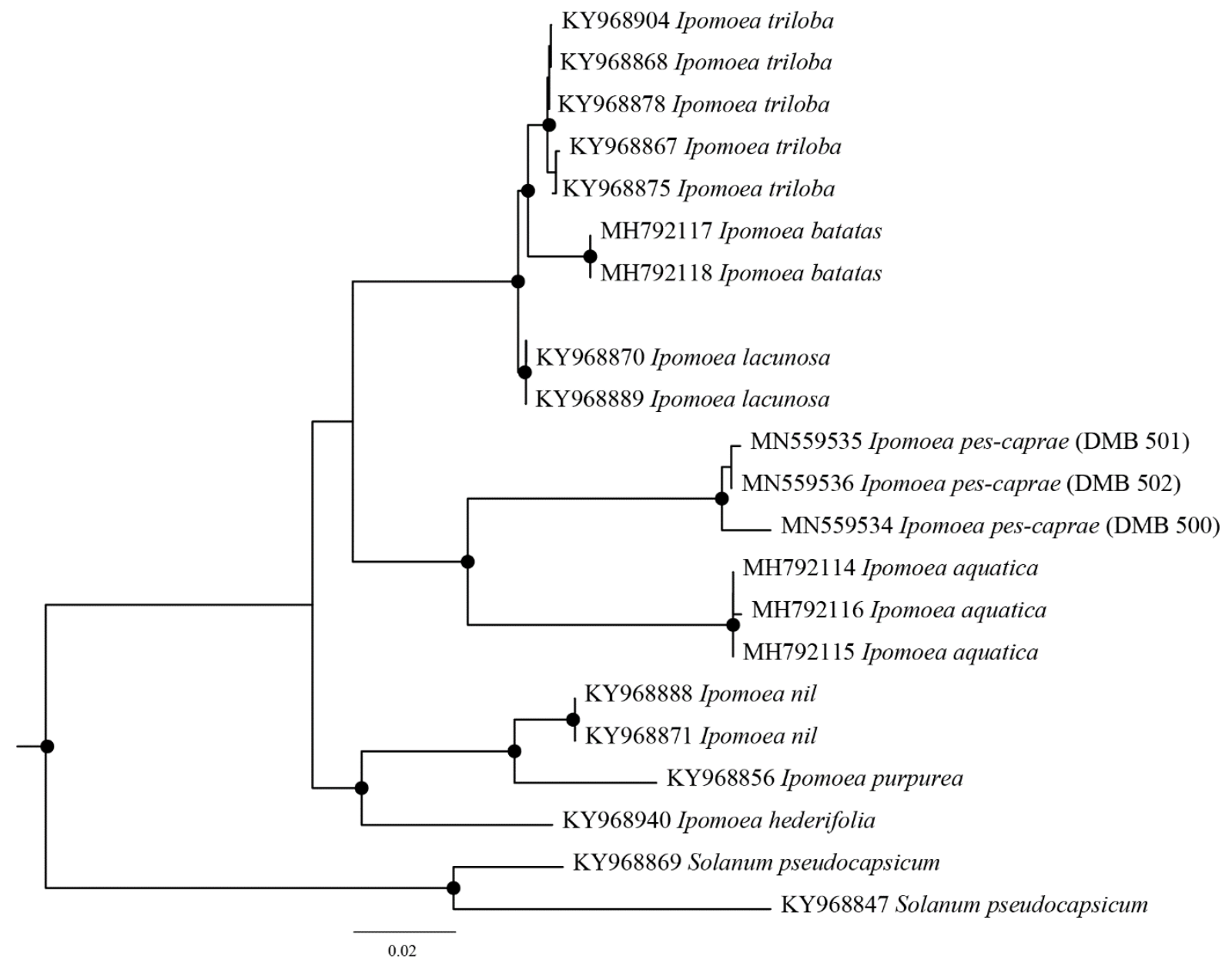

Figure 6: The NJ tree constructed for the marker ITS showing the phylogenetic relationships between Ipomoea spp. The black dots indicate the nodes that have bootstrap values over 70 . The scale bar represents the uncorrected pairwise genetic distance.

\section{Haplotype analysis}

For ITS and rbcL markers, all four Ipomoea spp.;

I. aquatica, I. batatas, I. nil, and I. pes-caprae shared unique haplotypes (Figs. 7 and 8). The ITS region of the four Ipomoea species contains a high degree of SNPs in comparison to the $r b c L$ region. A large INDEL of 24 nucleotides for ITS marker is present in I. batatas and I. nil, which can be helpful to distinguish I. batatas and I. nil form others. Whereas 14 SNPs can in the ITS region can be efficiently used to distinguish all four Ipomoea spp. from each other.

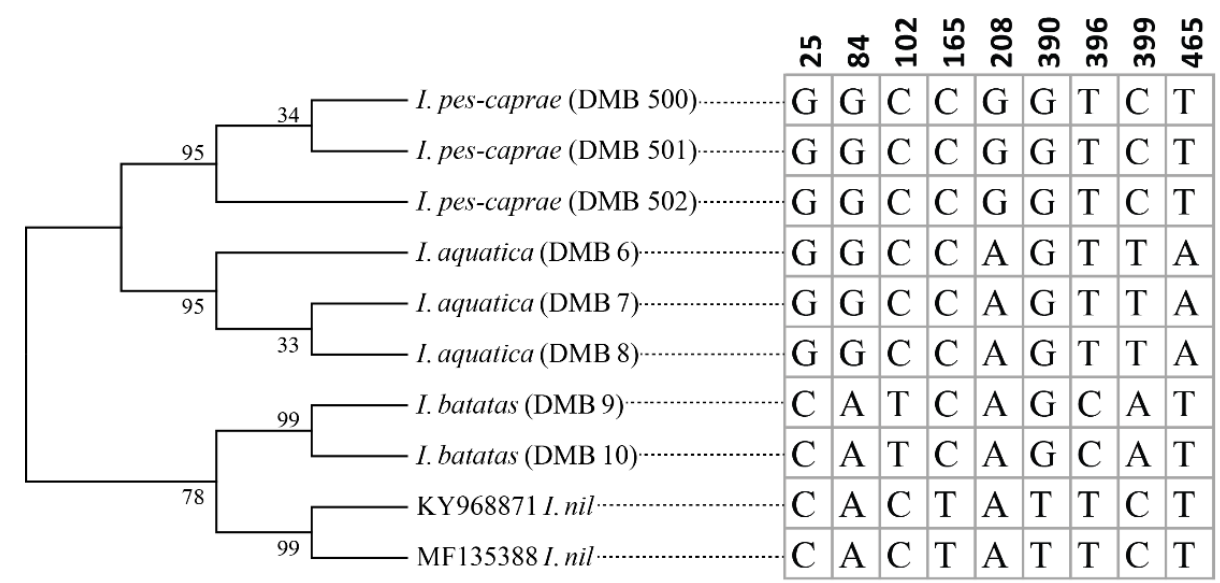

Figure 7: The $r b c L$ haplotypic polymorphism for the Ipomoea spp. assessed in the present study. There were 9 SNPs/indels detected among four species. The sequence alignment is shown with the base positions of the PCR products of $r b c L$ shown in the top. The UPGMA tree is placed in parallel to the sequence alignment to depict the interspecies variation. 


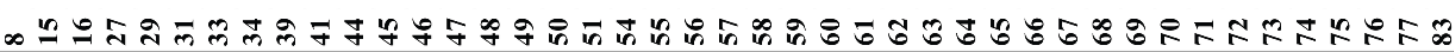

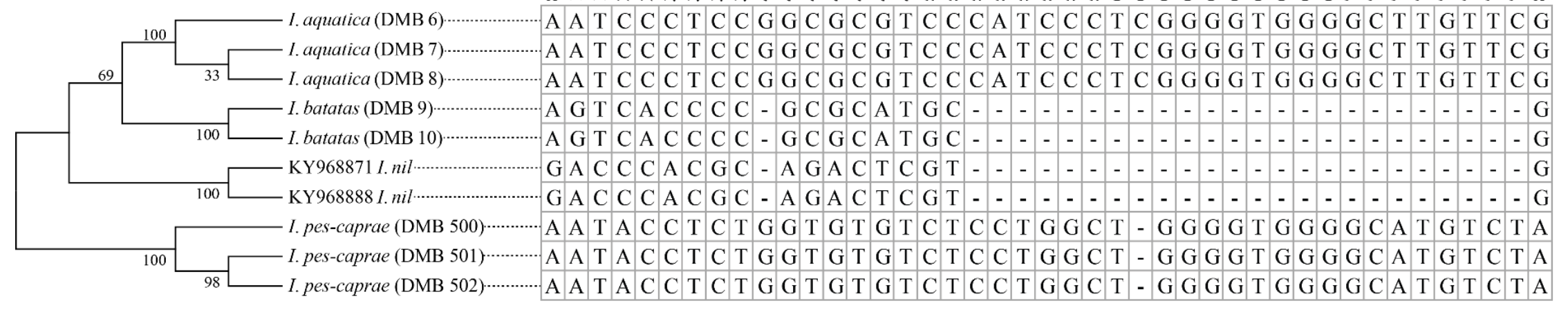

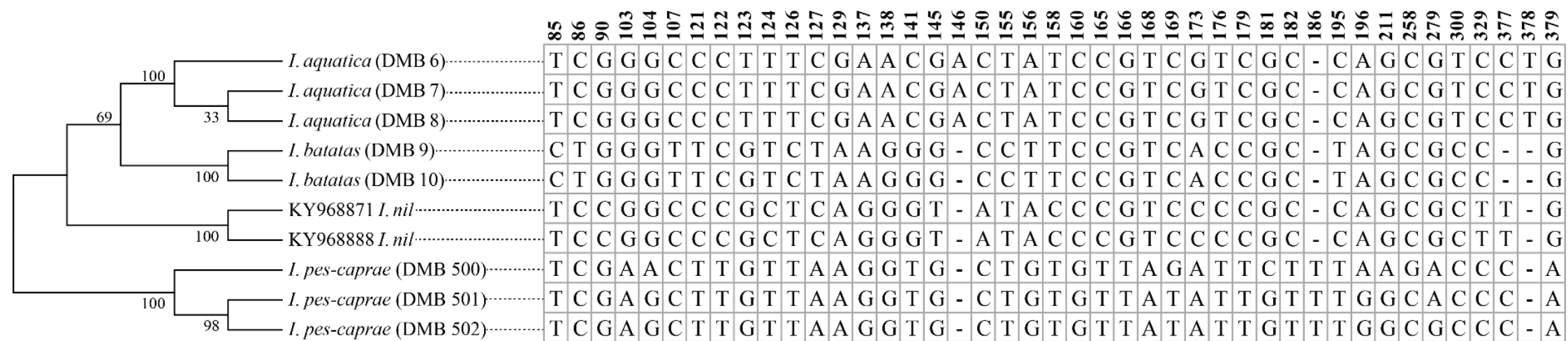

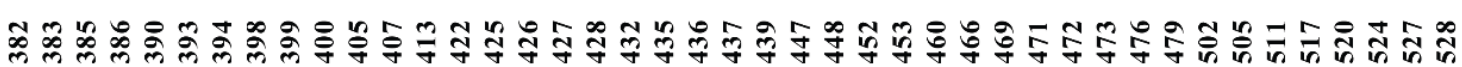

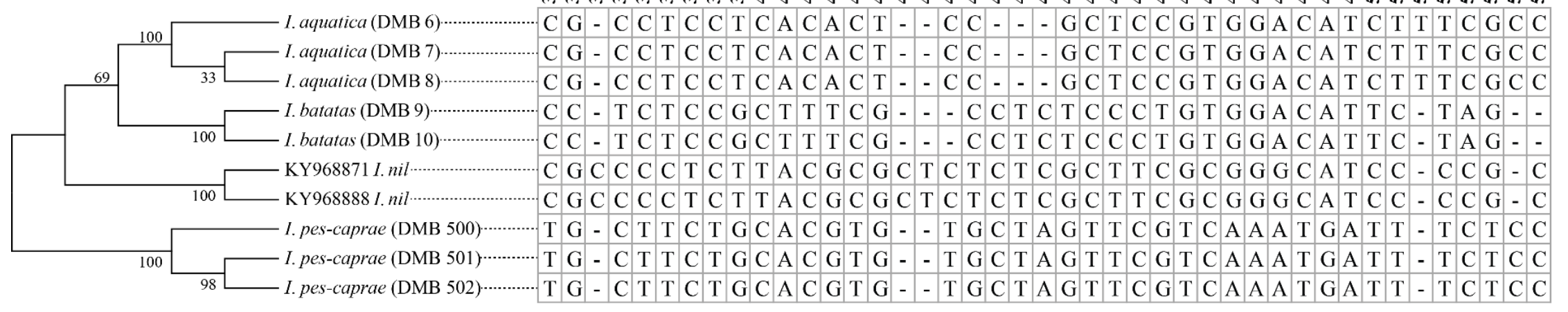

Figure 8: The ITS haplotypic polymorphism for the Ipomoea spp. assessed in the present study. There were 129 SNPs/indels detected among four species. The sequence alignment is shown with the base positions of the PCR products of ITS shown in the top. The UPGMA tree is placed in parallel to the sequence alignment to depict the interspecies variation. 


\section{Discussion}

The identification of Ipomoea species based on morphological analysis is somewhat challenging in scientific assessments. Many species share common features so that often, they can be misidentified and wrongly classified (Wilkin 1999; Taia 2005). However, some of the morphological characteristics are highly distinct in the four species studied (Figs. 1, 2, 3, and 4). Hence, for the general use the morphological key presented in this paper could be particularly useful. Further studies are needed to establish a comprehensive key for all the species given in Table 1.

The phylogenetic analysis revealed much information about the relatedness of these species. According to the results, the $r b c L$ marker is capable of delimiting I. nil, I. aquatica, and I. pes-caprae. I. aquatica is clustered sister to I. pes-caprae indicating that there was a close evolutionary similarity between the two species. This similarity further implies that the important genes could be transferred between I. aquatica and I. pes-caprae without much of a difficulty. However, $r b c L$ marker cannot delimit I. batatas species along with I. triloba and I. lacunosa. Moreover, the $r b c L$ marker makes a crown group which cannot be further delimited (Figs. 5 and 7). On the other hand, the ITS marker polymorphism can delimit I. nil, I. aquatica, and I. pes-caprae as in rbcL based tree. Moreover, it can discriminate against the crown group I. triloba, I. batatas, and I. lacunosa into individual species. According to ITS polymorphism, I. batatas is clustered as a sister group to I. triloba (Figs. 6 and 8). Due to the greater similarity among the members in Ipomoea genus, morphology-based identification is less accurate on certain occasions. Hence, the utilization of the DNA barcoding markers such as ITS, and $r b c L$, enhances the accuracy of species identification than morphology-based classical methods (Thorne 1992).

The most straightforward and powerful tool of the species differentiation is haplotype identification (Liu et al. 2008). According to the haplotype analysis, it is evident that all four Ipomoea species studied could be identified easily by using either $r b c L$ or ITS barcoding markers. The $r b c L$ haplotype contains only nine SNPs, while ITS haplotype is consisting of the 129 variations along with the indel. The haplotype analysis results obtained from 14 SNPs in the ITS regions can be used to distinguish all the four species separately (Figs. 7 and 8). Moreover, all the samples of the same species that are collected from different locations do not show any variation among their DNA sequences. This finding suggests that all the Ipomoea species within Sri Lanka share the same genetic architecture, although some of them are shown different morphologies. These variations may be due to phenotypic plasticity as a response to various geographical and climatic changes (Oostra et al. 2018). Therefore, this method of identification is crucial because these selected four species have a significant agricultural, economic, and ecological value compared to the other members of the Ipomoea genus. 
Tuber crops and leafy vegetable production in the world play a significant role in fighting against global hunger (Scott and Suarez 1992). Sweet potato is considered as the seventhlargest food crop grown in warm temperate, tropical, and sub-tropical regions around the world. Even though it is consumed in many south Asian countries, the commercial production of these crops remains at a meager rate (Tortoe et al. 2010; Ezin et al. 2018). Moreover, I. aquatica also holds a high degree of nutritional and medicinal value. It is considered as a leafy vegetable and consumed in many parts of the country. But no commercial cultivation can be seen in Sri Lanka. Therefore I. batatas and I. aquatica are classified as under-utilized crop plants in Sri Lanka despite their uses in diverse fields (Arachchi and Wijerathne 2007). Many far eastern and western countries have used I. nil (morning glory) as an ornamental plant (Shibuya 2012). However, in Sri Lanka, the growers are not aware of its ornamental value, so that the commercial cultivation is less common. The plant can only be seen in unused or abandoned lands. This plant is also highly invasive; hence proper control measures are needed to be taken (Hou et al. 2015). I. pes-caprae is widely found in the coastal line as a natural barrier against sea erosion. Its salttolerant property is highly valuable. It thrives through high salinity by expressing genes responsible for salt tolerance (Zhang et al. 2018) via biochemical tolerance mechanism related to osmotic stress and water deficiency. I. pes-caprae has a higher growth rate and grows rapidly into large beds covering the entire land area, which is ideal for preventing soil erosion.

However, considering the high range of abundance as well as the preference of the consumers, farmers could enhance the production of $I$. batatas because the sweet potatoes which are rich in carotenoids, which improvise the vitamin A component in children, especially in developing countries (van Jaarsveld et al. 2005). Also, it contains a lot of dietary fibre, vitamins, and minerals. Moreover, these crops provide supplementary food in rural areas (Burri 2011), whereas I. nil could be grown commercially to use as an ornamental plant. Moreover, any breeding attempt could be planned to introduce the genes responsible for salt-tolerance in I. pes-caprae into I. batatas. The activity and expression of ion channels responsible for this property are relatively higher in I. pes-caprae compared to other species in the Ipomoea genus (Venkatesan and Chellappan 1999). The salt tolerance ability could be further investigated using different marker alleles. Thereby, the identified genes could be used in marker-assisted breeding programs for the generation of novel and improved Ipomoea varieties.

\section{Conclusions}

The genus Ipomoea of family Convolvulaceae is one of the most diverse plant genera in the world. There are about 13 Ipomoea spp. documented in Sri Lanka. In an attempt to morpho genetically characterize the genus Ipomoea, we assessed four important members I. batatas, I. aquatica, I. nil, and I. pes-caprae. I. 
batatas and I. aquatica based on the food, medicinal, agricultural, and ecological values. Morphologically tuber bearing ability, flower color, and leaf shape can be used to delimit the selected species. Furthermore, out of the standard plant DNA barcoding markers ITS and $r b c L$, the sequence polymorphism in ITS can be used to define the species delimits in comparison to the world-wide Ipomoea germplasm.

\section{Acknowledgments}

The authors wish to thank the site owners for kindly providing access to the plants for observations and sample collection.

Conflicts of Interest: The authors declare that there are no conflicts of interest regarding the publication of this paper.

\section{References}

Akaike H (1974) Stochastic theory of minimal realization. IEEE Transactions on Automatic Control 19(6):667-674.

Antial B S, Akpanz E J, Okonl P A, Umorenl I U (2006) Nutritive and anti-nutritive evaluation of sweet potatoes. Pak J Nutr 5(2):166-168.

Arachchi D H M, Wijerathne P M (2007) Country report on the state of plant genetic resources for food and agriculture, Sri Lanka. Available at: http://www.fao.org/3/i1500e/ SriLanka.pdf. accessed on: 15 January 2020.
Austin D F, Huáman Z (1996) A synopsis of Ipomoea (Convolvulaceae) in the Americas. Taxon 45(1):3-38.

Ayurveda Medical Plants of Sri Lanka (2020). Available at: http://www.instituteofayurveda.org/plants. accessed on: 1 April 2020.

Ayurvedic medicinal plants in Sri Lanka (AMPSL) (2020) Ipomoea batatas. Available at: http://www.instituteofayurveda.org/plants/pl ants_detail.php?i=337\&s=Local_name. accessed on: 2 of April 2020.

Bach C (1998) Interactive effects of herbivory and sand burial on growth of a tropical dune plant, Ipomoea pes-caprae. Ecol Entomol 23(3):238-245.

Bragadeeswaran S, Prabhu K, Rani S S, Priyadharsini S, Vembu N (2010) Biomedical application of beach morning glory Ipomoea pes-caprae. Int J Trop Med 5(4):81-85.

Burri B J (2011) Evaluating sweet potato as an intervention food to prevent vitamin $A$ deficiency. Comprehensive Reviews in Food Science and Food Safety 10(2):118-130.

Cavanaugh J E (1997) Unifying the derivations for the Akaike and corrected Akaike information criteria. Statistics and Probability Letters 33:201-208.

Das S, Mukherjee K K (1997) Morphological and biochemical investigations on Ipomoea 
seedlings and their species inter relationships. Ann Bot 79(5):565-571.

Der Marderosian A H, Hauke R L, Youngken H W (1964) Preliminary studies of the comparative morphology and certain indoles of Ipomoea seeds. Econ Bot 18(1):67-76.

Devall M S (1992) The biological flora of coastal dunes and wetlands. 2. Ipomoea pes-caprae (L.) Roth. J Coas Res 8(2):442-456.

Doyle J J, Doyle J L (1990) Isolation of plant DNA from fresh tissue. Focus 12:13-15.

Edie H, Ho B (1969) Ipomoea aquatica as a vegetable crop in Hong Kong. Econ Bot 23:3236.

Ezin V, Quenum F, Bodjrenou R H, Kpanougo C M, Kochoni E M, Chabi B I, Ahanchede A (2018) Assessment of production and marketing constraints and value chain of sweet potato in the municipalities of Dangbo and Bonou. Agric Food Secur 7(1):15.

Gothberg A, Greger M, Bengtsson B (2002) Accumulation of heavy metals in water spinach (Ipomoea aquatica) cultivated in the Bangkok region. Thailand. Environ Toxicol Chem 21:1934-1939.

Hou Y P, Peng S L, Lin Z G, Huang Q Q Ni G Y, Zhao N (2015) Fast-growing and poorly shadetolerant invasive species may exhibit higher physiological but not morphological plasticity compared with non-invasive species. Biol Invasions 17(5):1555-1567.

Hue S M, Chandran S, Boyce A N (2010) Variations of leaf and storage roots morphology in Ipomoea batatass L. (Sweet potato) cultivars. In Asia Pacific Symposium on Postharvest Research, Education and Extension, 943, pp. 7379.

Huxley A (1992) The New RHS Dictionary of Gardening. MacMillan Press, New York.

Izawa G, Okamoto S (1959) Effect of mineral nutrition on contents of organic constituents in sweet potato plants during growth. J Soil Sci Plant Nutr 4(4):163-170.

Jayeola A A, Oladunjoye O R (2012) Systematic studies in some Ipomoea Linn. Species using pollen and flower morphology. Annals of West University of Timisoara: Series of Biology 15(2):177.

Kailasapathy K, Koneshan T (1986) Effect of wilting on the ascorbate content of selected fresh green leafy vegetables consumed in Sri Lanka. J Agric Food Chem 34(2):259-261.

Kajita Y, Nishino E (2009) Morphology and anatomy of leaves and flowers of wild-type and pleiotropic maple-willow mutant in Japanese morning glory (Ipomoea nil). J Jpn Soc Hortic Sci 78(3):369-380.

Kumar S, Stecher G, Tamura K (2016) MEGA7: Molecular Evolutionary Genetics Analysis 
version 7.0 for bigger datasets. Mol Biol Evol 33(7):1870-1874.

Lebot V (2009) Tropical root and tuber crops: cassava, sweet potato, yams and aroids. Wallingford: CABI.

Liu N, Zhang K, Zhao H (2008) Haplotype-association analysis. Adv Genet 60:335-405.

Lobin W (1986) On a collection of Convolvulaceae from the Cape Verde Islands. Willdenowia.

Madhvi S, Sharma K C, Manju S (2014) Study of Morphological Characteristics of Spinach Irrigated with Industrial wastewater of Bhiwadi, Rajasthan, India. Int Res J Env Sci 3(3):31-38.

Miller M A, Pfeiffer W, Schwartz T (2010) Creating the CIPRES Science Gateway for inference of large phylogenetic trees. 2010 Gateway Computing Environments Workshop (GCE): 1-8.

Oostra V, Saastamoinen M, Zwaan B J, Wheat C W (2018) Strong phenotypic plasticity limits potential for evolutionary responses to climate change. Nat Commun 9(1):1-11.

Posada D (2008) jModelTest: phylogenetic model averaging. Mol Biol Evol 25(7):12531256.
Purseglove J W (1974) Tropical crops. Dicotyledons. Longman Press, London.

Rambaut A (2014). FigTree, a graphical viewer of a phylogenetic trees. Available at: http://tree. bio. ed.ac. uk/software/figtree13/ 06/2019. accessed on: 30 of March 2020.

Ranathunga A P, Ranasinghe R D, Jayarathne H S, Thilakarathne S M, Karunarathne S I, Ranaweera L T, Ananda G K, Kannangara S K, Meepegamage S W, Sooriyapathirana S D (2019) X-ray Fluorescence Analysis and Consumer Preference Assessment Unveils that Sweet Potato Shoot-Tops are a Safer Alternative to Water Spinach, a Leafy Vegetable Prone to Bioaccumulation of Heavy Metals. JAS-SL 14(3):181-200.

Scott G J, Suarez V (1992) Transforming traditional food crops: product development for roots and tubers. Product Development for Root and Tuber Crops 1:3-20.

Shibuya K (2012) Molecular mechanisms of petal senescence in ornamental plants. J Jpn Soc Hortic Sci 81(2):140-149.

Swofford D L (2002) PAUP* version 4.0. Phylogenetic analysis using parsimony (and other methods).

Taia W K (2005) Modern trends in plant taxonomy. Asian J Plant Sci 4(2):2005. 
Thorne R F (1992) An updated phylogenetic classification of the flowering plants. Aliso: A J Syst Evol Bot 13(2):365-389.

Tortoe C, Obodai M. Amoa-Awua W (2010) Microbial deterioration of white variety sweet potato (Ipomoea batatas) under different storage structures. In J Plant Biol 1(1):e10-e10.

Umar K J, Hassan L G, Dangoggo S M, Ladan M J (2007) Nutritional Composition of Water Spinach (Ipomoea aquatica Forsk.) Leaves. J Appl Sci 7(6):803-809.

Venkatesan A, Chellappan K P (1999) Salinity effect on the activities of certain antioxidant enzymes in Ipomoes pes-caprae sweet, a halophyte. Indian J Plant Physiol 4:40-42.

van Jaarsveld P J, Faber M, Tanumihardjo S A, Nestel P, Lombard C J, Benadé A J (2005) $\beta$ Carotene-rich orange-fleshed sweet potato improves the vitamin A status of primary school children assessed with the modified-relativedose-response test. Am J Clin Nutr 81(5):10801087.

Wang H W, Kawaguchi S, Horiguchi T, Masuda $M$ (2001). A morphological and molecular assessment of the genus Prionitis J. Agardh (Halymeniaceae, Rhodophyta). Phycological research 49(3):251-261.

White T J, Bruns T, Lee S J, Taylor J L (1990) Amplification and direct sequencing of fungal ribosomal RNA genes for phylogenetics. PCR
Protocols: A Guide to Methods and Applications 18(1):315-322.

Wickramasinghe H A, Takigawa S, MatsuuraEndo C, Yamauchi H, Noda T (2009) Comparative analysis of starch properties of different root and tuber crops of Sri Lanka. Food Chem 112(1):98-103.

Wilkin P A (1999) Morphological cladistic analysis of the Ipomoeeae (Convolvulaceae). Kew Bulletin 1:853-876.

Xu S Z, Li Z Y, Jin X H (2018) DNA barcoding of invasive plants in China: A resource for identifying invasive plants. Mol Ecol Resour 18(1):128-136.

Zhang M, Zhang H, Zheng J X, Mo H, Xia K F, Jian S G (2018) Functional identification of saltstress-related genes using the FOX hunting system from Ipomoea pes-caprae. Int J Mol 19(11):3446. 